\title{
Crop siderat as a method of biological function in the southwestern part of the central black- earth region
}

\author{
S. Smurov*, S. Kulkov, O. Grigorov, and $Y u$. Shchedrina \\ Belgorod State Agricultural University named after V. Gorin, Mayskiy, Belgorod region, Russia
}

\begin{abstract}
The article presents the results of long-term experience in the study of crop crops and their impact on the growth conditions and yield of the following crops. The reaped siderates were sown after winter and spring wheat in a 4-field crop rotation. The results of the research work showed that it is less likely to get their good shoots after spring wheat than after winter wheat, and the total plant mass of siderate introduced into the soil over all the years after it was 54-66 t / ha, which is about 1.7 times lower than after winter culture. The incorporation of the organic mass of the crop material into the soil in most years of its cultivation provided a positive balance of humus. The infestation of the crop sown next to the crop siderate increased only when using mineral fertilizer by 1.4-1.7 times compared to crops without it, while the number of perennial dicotyledonous weeds increased by an average of 2.5-3 times, both when applying azofoska and without it. The yield of crops following siderates in the crop rotation with the predecessor of winter wheat, peas for grain, was not significantly higher compared to crops without siderates, and with the predecessor, the sideral pair was slightly lower.
\end{abstract}

\section{Introduction}

The use of green manure as an organic fertilizer is one of the most significant methods of farming biologization $[1,13,14]$. Losses of humus due to mineralization in the conditions of modern farming are not compensated [2]. A good technique for the reproduction of soil fertility is the application of cattle manure (cattle manure), but due to organizational (especially logistical) and economic reasons its use is very limited. In such circumstances, the search for a replacement for manure inevitably leads to green manure. According to the assessment of S. V. Lukin, embedding 20 tons of green mass of white mustard in the soil is equivalent to the introduction of 10-12 tons of cattle manure [3]. In general, taking into account the data of studies B.M. Kogut showing that over the year in the arable layer of black earth mineralized about $400 \mathrm{~kg}$ / ha humus [4], then to fully compensate for its loss only due to stubble siderat need, depending on the value of the coefficient of humification, get 2.5-5.7 $\mathrm{t} /$ ha of dry matter per year [5]. The results of the researches prove that the application of crop siderat reduces the weediness of the following crop [6]; in combination with stubble and

\footnotetext{
*Corresponding author: smurov_si@bsaa.edu.ru
} 
root residues of the main crop its use increases its productivity $[7,8]$ and improves the agrochemical $[9,15-18]$ and agrophysical properties of soil $[10,19,20]$.

\section{Materials and methods of research}

Studies on the effectiveness of crop residue sideration were carried out in a multi-year stationary experiment, laid in 2000 in the Belgorod State Agrarian University. The soil of the experimental plot is typical chernozem. Agrochemical research carried out in 2004 showed that it contained 4,7\% humus, $153 \mathrm{mg} / \mathrm{kg}$ of readily hydrolysable nitrogen by Kornfield, 154 $\mathrm{mg} / \mathrm{kg}$ of mobile phosphorus, and $122 \mathrm{mg} / \mathrm{kg}$ of exchangeable potassium by Chirikov. Hydrolytic acidity was $5.9 \mathrm{mg} / \mathrm{eq} .100 \mathrm{~g}$ of soil, sum of absorbed bases $37.1 \mathrm{mg} / \mathrm{eq}$. per 100 $\mathrm{g}$ of soil, $\mathrm{pH}_{\text {сол }}=5.3$.

Crops in the four-field crop rotation alternated in the following order: winter wheat - winter wheat - soybeans - spring wheat. From 2006 to 2011 winter wheat was preceded by leguminous crops, since 2012 it was preceded by green manure. After harvesting of cereals in the rotation in half of the area was sown with stubble siderat, and the other half was left to control without siderat. White mustard was used as a stubby green manure.

The research scheme included 4 systems of fertilizers: without fertilizers - control; mineral nutrition in a dose of $\mathrm{N}_{30} \mathrm{P}_{30} \mathrm{~K}_{30} \mathrm{~kg} / \mathrm{ha}$ a.d. in the form of NPK under all crops of the rotation; crop siderat after spike crops; crop siderat after spike crops with the application of NPK in a dose $\mathrm{N}_{30} \mathrm{P}_{30}{ }_{30} \mathrm{~K} \mathrm{~kg} / \mathrm{ha}$ a.d. under all crops of the rotation. When sowing winter wheat the whole norm of mineral fertilizers was applied at once. For other crops fractional application was used $-20 \mathrm{~kg} / \mathrm{ha}$ a.m. under autumn tillage or when sowing stubble siderat, and the remaining $10 \mathrm{~kg} / \mathrm{ha}$ a.m. when sowing the crop itself.

Plot placement was systematic, with splitting. Accounting of green mass of the crop siderat was carried out by mowing and weighing in the field with the collection of plant samples for further determination of the chemical composition in the testing laboratory of the University. Counting the number of weeds in all years was performed before the first treatment of the crop with herbicides by frame method.

Agronomic techniques in the experiment were common for the CKR, except for the following details: in the period from 2006 to 2012, stubble crops were sown after ploughing the stubble of the predecessor and were not incorporated into the soil until the spring. Between 2012 and 2015, they were sown on uncultivated wheat stubble using a direct seed drill, also without incorporation into the soil until spring. Starting from 2016, we abandoned direct seeding and started to sow the green manure after mechanical treatment of the stubble of the predecessor with its embedding in the soil in autumn during the main tillage.

Conversion to the dry matter of green mass of green manure was carried out according to the data of chemical analysis of plants (Table 4). The mass of straw and crop-root residues of all crops of the crop rotation was calculated on the basis of data from the sheep samples according to the variants of the experiment.

Conversion of straw and crop-root residues, as well as yield data of dry weight of green manure into organic matter was performed with a coefficient of 0.8 , and applied organic matter into humus with a humification coefficient of 0.2 .

As an indicator of the level of moisture availability in the territory, long-term data from the weather station of Belgorod State Agrarian University were used.

\section{Research results and their discussion}

During the 15 years of the experiment, the crop yield of green mass of crop siderat varied significantly depending on the crop, on which stubble it was sown and the use of mineral 
fertilizers, but in most cases its value was influenced by hydrothermal conditions in the period after sowing and during the growth of white mustard (Table 1). The maximum yield of green mass of crop siderat for all years of the experiment was obtained in 2012 with the use of mineral fertilizers. After winter wheat it was $35.3 \mathrm{t} / \mathrm{ha}$ and after spring wheat it was $30.7 \mathrm{t} / \mathrm{ha}$.

Table 1. Yield of green mass of crop siderat in 2006-2020, t/ha.

\begin{tabular}{|c|c|c|c|c|c|c|c|c|c|c|c|c|c|c|c|c|c|}
\hline Culture & $\begin{array}{l}\text { Fertilizer } \\
\text { system }\end{array}$ & ஜั & હे̊ & ¿્ণ & ڤे̀ & $\stackrel{\circ}{\circ}$ & $\overrightarrow{\vec{\sim}}$ & $\stackrel{\text { กิ }}{\overline{2}}$ & $\stackrel{m}{\stackrel{2}{\sim}}$ & $\stackrel{+}{\stackrel{4}{\sim}}$ & $\stackrel{n}{\stackrel{n}{~}}$ & $\stackrel{\circ}{\circ}$ & $\overrightarrow{\text { กे }}$ & $\stackrel{\infty}{\stackrel{\sim}{\sim}}$ & 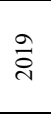 & હે & $\begin{array}{c}\text { In the } \\
\text { middle.., } \\
\text { NSR }_{05}= \\
2.1\end{array}$ \\
\hline \multirow{2}{*}{$\begin{array}{l}\text { Winter } \\
\text { wheat }\end{array}$} & Sidctal & 14,6 & 5,5 & 2,4 & 5 & 0 & 3,3 & 3,3 & $\overline{5,6}$ & 4,8 & 0,8 & 7,2 & 4,7 & 4,6 & 1,1 & 0 & 6,0 \\
\hline & Min.-sider. & 20,0 & 7,6 & 4,3 & 2,6 & 0 & 4,7 & 35,3 & 6,4 & 4,9 & 0,8 & $\begin{array}{c}15, \\
3\end{array}$ & 5,1 & 4,5 & 0,5 & 0 & 7,5 \\
\hline \multirow{2}{*}{$\begin{array}{l}\text { spring } \\
\text { wheat }\end{array}$} & Sideral & 8,5 & 11,0 & 1,8 & 0 & 0 & 4,1 & 27,3 & 0,1 & 0 & 0 & 0,9 & 0,4 & 0 & 0 & 0 & 3,6 \\
\hline & Min.-sider. & 11,6 & 13,1 & 2,4 & 0 & 0 & 6,3 & 30,7 & 0,2 & 0 & 0 & 1,3 & 0,5 & 0 & 0 & 0 & 4,4 \\
\hline
\end{tabular}

In general, after winter wheat received more green mass of green manure, because its seeds were due to the earlier harvesting compared to spring wheat in more favorable conditions. Therefore, sown after winter wheat siderat, germinated quite stably. In some years, this was due to good residual soil moisture reserves, but more often and mainly due to rainfall in late July and early August (Table 2). (Table 2)

Table 2. Every ten days sum of precipitation during vegetation period of stubble siderat after winter wheat in 2006-2020.

\begin{tabular}{|c|c|c|c|c|c|c|c|c|c|c|c|}
\hline \multirow{3}{*}{ Years } & \multirow{3}{*}{\begin{tabular}{|c|} 
Vegetation \\
period of the \\
crop protection \\
grass \\
\end{tabular}} & \multicolumn{10}{|c|}{ Months and decades } \\
\hline & & \multirow{2}{*}{$\begin{array}{c}\text { July } \\
3 \\
\end{array}$} & \multicolumn{3}{|c|}{ August } & \multicolumn{3}{|c|}{ September } & \multicolumn{3}{|c|}{ October } \\
\hline & & & 1 & 2 & 3 & 1 & 2 & 3 & 1 & 2 & 3 \\
\hline 2006 & $29.07-14.10$ & & 15,4 & 0,9 & 57,3 & 56,7 & 1,1 & 4,0 & 17,8 & 5,0 & \\
\hline 2007 & $18.07-12.10$ & 29,3 & 25,5 & 1,1 & 6,4 & 19,8 & 28,3 & 61,5 & 32,2 & & \\
\hline 2008 & $4.08-16.10$ & & 22,7 & 0 & 11,3 & 1,1 & 21,4 & 17,7 & 44,4 & 8,2 & \\
\hline 2009 & $21.07-6.10$ & 9,1 & 4,1 & 0 & 8,1 & 11,0 & 3,1 & 2,2 & 5,1 & & \\
\hline 2010 & $15.07-15.10$ & 25,0 & 0,5 & 17,0 & 29,0 & 32,7 & 6,9 & 33,6 & 15,0 & & \\
\hline 2011 & $22.07-28.10$ & 16,5 & 2,2 & 0 & 5,5 & 4,3 & 1,2 & 2,3 & 13,6 & 15,1 & 0 \\
\hline 2012 & $20.07-22.10$ & 6,2 & 3,0 & 19,7 & 80,2 & 8,1 & 8,1 & 0 & 21,6 & 37,2 & \\
\hline 2013 & $17.07-30.10$ & 8,0 & 35,7 & 0 & 4,1 & 13,9 & 26,0 & 53,3 & 4,4 & 26,0 & 16,8 \\
\hline 2014 & $21.07-4.10$ & 4,6 & 1,4 & 2,5 & 21,1 & 0 & 0 & 23,9 & 0,0 & & \\
\hline 2015 & $27.07-2.10$ & & & 0,4 & 0 & 2,3 & 6,2 & 0,4 & & & \\
\hline 2016 & $16.08-21.10$ & 58,2 & 48,5 & 100,5 & 9,1 & 0 & 0 & 7,9 & 41,1 & 4,4 & \\
\hline 2017 & $11.08-4.10$ & 29,0 & 14,2 & 0 & 12,6 & 24,5 & 0 & 0 & 14,2 & & \\
\hline 2018 & $6.08-09.10$ & & 0 & 1,0 & 0 & 3,3 & 2,8 & 21,4 & 5,9 & & \\
\hline 2019 & 15.07-25.09 & 10,0 & 1,0 & 0 & 0 & 0 & 1,0 & 25,2 & & & \\
\hline 2020 & $13.08-28.10$ & & & 0 & 11,4 & 0 & 0 & 3,1 & 0 & 17,4 & 4,0 \\
\hline
\end{tabular}

Late harvested spring wheat generally left less soil moisture after harvest than winter wheat. In addition, sown after it siderat less often received sufficient rainfall, as August and September are often dry (Table 3). Therefore, winter wheat stubble did not sprout only in 2010 and in 2020, while spring wheat did so 2.5 times more often. There were several years when spring wheat stubble sprouting was so weak and thinned that the value of the formed green mass did not exceed $0.2 \mathrm{t} /$ ha (Table 1$)$. 
Table 3. Every ten days sum of precipitation during vegetation period of stubble siderat sown after spring wheat in 2006-2020.

\begin{tabular}{|c|c|c|c|c|c|c|c|c|c|c|c|}
\hline \multirow{3}{*}{ Years } & \multirow{3}{*}{$\begin{array}{l}\text { Vegetation period } \\
\text { of the crop } \\
\text { protection grass }\end{array}$} & \multicolumn{10}{|c|}{ Months and decades } \\
\hline & & \multirow{2}{*}{$\begin{array}{c}\text { July } \\
3 \\
\end{array}$} & \multicolumn{3}{|c|}{ August } & \multicolumn{3}{|c|}{ September } & \multicolumn{3}{|c|}{ October } \\
\hline & & & 1 & 2 & 3 & 1 & 2 & 3 & 1 & 2 & 3 \\
\hline 2006 & $18.08-14.10$ & & & & 57,3 & 56,7 & 1,1 & 4,0 & 17,8 & 5,0 & \\
\hline 2007 & $7.08-12.10$ & & & 1,1 & 6,4 & 19,8 & 28,3 & 61,5 & 32,2 & & \\
\hline 2008 & $4.08-16.10$ & & 22,7 & 0 & 11,3 & 1,1 & 21,4 & 17,7 & 44,4 & 8,2 & \\
\hline 2009 & $4.08-6.10$ & & 4,1 & 0 & 8,1 & 11,0 & 3,1 & 2,2 & 5,1 & & \\
\hline 2010 & $25.07-15.10$ & & 0,5 & 17,0 & 29,0 & 32,7 & 6,9 & 33,6 & 15,0 & 16,1 & \\
\hline 2011 & $22.07-28.10$ & 16,5 & 2,2 & 0 & 5,5 & 4,3 & 1,2 & 2,3 & 13,6 & 15,1 & 0 \\
\hline 2012 & $1.08-22.10$ & & 3,0 & 19,7 & 80,2 & 8,1 & 8,1 & 0 & 21,6 & 37,2 & \\
\hline 2013 & $31.07-30.10$ & & 35,7 & 0 & 4,1 & 13,9 & 26,0 & 53,3 & 4,4 & 26,0 & 16,8 \\
\hline 2014 & $7.08-4.10$ & & & 2,5 & 21,1 & 0 & 0 & 23,9 & 0,0 & & \\
\hline 2015 & $6.08-2.10$ & & 0 & 0,4 & 0 & 2,3 & 6,2 & 0,4 & & & \\
\hline 2016 & $18.08-21.10$ & & & & 9,1 & 0 & 0 & 7,9 & 41,1 & 4,4 & \\
\hline 2017 & $11.08-4.10$ & & & 0 & 12,6 & 24,5 & 0 & 0 & 14,2 & & \\
\hline 2018 & $6.08-09.10$ & & 0 & 1,0 & 0 & 3,3 & 2,8 & 21,4 & 5,9 & & \\
\hline 2019 & $30.07-25.09$ & & 1,0 & 0 & 0 & 0 & 1,0 & 25,2 & & & \\
\hline 2020 & $13.08-28.10$ & & & 0 & 11,4 & 0 & 0 & 3,1 & 0 & 17,4 & 4,0 \\
\hline
\end{tabular}

The average annual dry organic matter yield due to biomass of crop siderat differed depending on the use of mineral fertilizers and crop rotation, after which it was sown. Syderal sowing after winter wheat gave almost 1.7 times more dry matter than after spring grain crop (Table 5). The application of mineral fertilizer increased this indicator by $23-25 \%$ relative to variants without it.

Table 4. Content of dry organic matter and nutrients in the dry weight of crop residues.

\begin{tabular}{|c|c|c|c|}
\hline \multirow{2}{*}{$\begin{array}{c}\text { Dry organic matter } \\
\text { content, } \%\end{array}$} & $\mathrm{~N}$ & $\mathrm{P}_{2} \mathrm{O}_{5}$ & $\mathrm{~K}_{2} \mathrm{O}$ \\
\cline { 2 - 4 } & 1,92 & 0,36 & 1,68 \\
\hline 21,8 & &
\end{tabular}

Table 5. Input of dry organic matter and nutrients into the soil with stubble siderat in 2006-2020.

\begin{tabular}{|c|c|c|c|c|c|c|}
\hline \multirow{2}{*}{$\begin{array}{l}\text { The crop after } \\
\text { which the green } \\
\text { manure was } \\
\text { sown }\end{array}$} & \multirow[t]{2}{*}{ Fertilizer system } & \multirow{2}{*}{$\begin{array}{c}\text { Average } \\
\text { annual dry } \\
\text { matter input, } \\
\text { t/ha }\end{array}$} & \multirow{2}{*}{$\begin{array}{l}\text { Total dry } \\
\text { matter input, } \\
\text { t/ha }\end{array}$} & \multicolumn{3}{|c|}{$\begin{array}{c}\text { Total nutrient inputs with } \\
\text { mass of crop residues, } \\
\mathrm{kg} / \mathrm{ha}\end{array}$} \\
\hline & & & & $\mathrm{N}$ & $\mathrm{P}_{2} \mathrm{O}_{5}$ & $\mathrm{~K}_{2} \mathrm{O}$ \\
\hline \multirow{2}{*}{ Winter wheat } & Sideral & 1,31 & 19,65 & 377 & 71 & 330 \\
\hline & Mineral-sederal & 1,64 & 24,60 & 472 & 89 & 413 \\
\hline \multirow{2}{*}{ spring wheat } & Sideral & 0,78 & 11,70 & 225 & 42 & 197 \\
\hline & Mineral-sederal & 0,96 & 14,40 & 276 & 52 & 242 \\
\hline
\end{tabular}

In 2006-2009, the difference in weed infestation and species composition in the crops sown in the first and third fields, relative to the control without fertilizer after crop siderat and with mineral fertilizer only, was small (Table 6). Thus, the increase of weed infestation for these years averaged $2.5-10.5 \%$, and the variant with a single siderat had no effect on the number of weeds or their species composition in the soybean crops. But the combined use of mineral fertilizers and crop siderat led to a significant increase in weed infestation of the following crop in the average four years of the precursor of winter wheat by $31.0 \%$, and soybean by $67.8 \%$. 
The measurements of weed vegetation in the sideral fallow field in 2017-2020 showed that in the variant with stubby sideratom there was a decrease in the total number of weeds relative to the control, and on average for four years it was $11.8 \%$, and in the soybean field $5.6 \%$. The use of mineral fertilizers, both alone and in combination with crop siderat led to an increase in weed infestation of these crops. At the mineral system of fertilizers the amount of weeds on both fields increased approximately equally about $20 \%$, and at mineral-sideral in the precursor of winter wheat by $28 \%$, and in soybean by $207 \%$. At the same time, where mineral fertilizers were applied in combination with green manure, there was an increase in the number of weeds and relative to the crops only with mineral nutrition of crops of the rotation. At the same time, it should be noted that if in the field of winter wheat predecessors, it barely exceeded 5\%, in the field of soybeans growth reached $155 \%$.

Table 6. Average weed infestation of crops following the crop siderat, depending on the fertilizer system applied in 2006-2009 and 2017-2020, ex/m² .

\begin{tabular}{|c|c|c|c|c|c|c|c|c|}
\hline \multirow{3}{*}{ Crop rotation } & \multicolumn{8}{|c|}{ Fertilizer system, number of weeds } \\
\hline & \multicolumn{2}{|c|}{$\begin{array}{l}\text { Without fertilizer } \\
\text { (control) }\end{array}$} & \multicolumn{2}{|c|}{$\mathrm{N}_{30} \mathrm{P}{ }_{30} \mathrm{~K}_{30}$} & \multicolumn{2}{|c|}{ Stubble grass } & \multicolumn{2}{|c|}{$\begin{aligned} & \mathrm{N}_{30} \mathrm{P}_{30} \mathrm{~K}_{30} \\
+ & \text { Stubble grass }\end{aligned}$} \\
\hline & $\begin{array}{l}2006- \\
2009 .\end{array}$ & $\begin{array}{l}2017- \\
2020 .\end{array}$ & $\begin{array}{l}2006- \\
2009 .\end{array}$ & $\begin{array}{l}2017- \\
2020 .\end{array}$ & $\begin{array}{l}2006- \\
2009 .\end{array}$ & $\begin{array}{l}2017- \\
2020 .\end{array}$ & $\begin{array}{l}2006- \\
2009 .\end{array}$ & $\begin{array}{l}2017- \\
2020 .\end{array}$ \\
\hline $\begin{array}{l}\text { Winter wheat } \\
\text { precursors* }\end{array}$ & 116 & 110 & 119 & 134 & 127 & 97 & 152 & 141 \\
\hline Soya & 115 & 89 & 127 & 107 & 114 & 84 & 193 & 273 \\
\hline Average & 115 & 100 & 123 & 121 & 120 & 91 & 172 & 207 \\
\hline
\end{tabular}

The crop siderat influenced the species composition of weeds in the fields of the following crops. The weeds were divided into three groups - cereals, annual dicotyledons and perennial dicotyledons. Perennial dicotyledonous weeds were represented mainly by field sow thistle and field thistle. These species accounted for more than $93 \%$ of the total abundance of this group. (Table 7)

Table 7. Weed infestation of crop rotation fields with the use of stubble sodding by different species of weeds depending on the applied fertilizer system on average for 2017-2020, indices $/ \mathrm{m}^{2}$.

\begin{tabular}{|c|c|c|c|c|c|c|c|c|c|c|c|c|}
\hline \multirow{3}{*}{ Crop rotation } & \multicolumn{12}{|c|}{ Fertilizer system, weed species* } \\
\hline & \multicolumn{3}{|c|}{$\begin{array}{c}\text { Without fertilizer } \\
\text { (control) }\end{array}$} & \multicolumn{3}{|c|}{$\mathrm{N}_{30} \mathrm{P}_{30} \mathrm{~K}_{30}$} & \multicolumn{3}{|c|}{ Stubble grass } & \multicolumn{3}{|c|}{$\begin{aligned} & \mathrm{N}_{30} \mathrm{P}_{30} \mathrm{~K}_{30} \\
+ & \text { Stubble grass }\end{aligned}$} \\
\hline & OHS & UDF & MDS & OHS & UDF & MDS & OHS & UDF & MDS & OHS & UDF & MDS \\
\hline Sideral steam & 40 & 68 & 2 & 38 & 94 & 2 & 25 & 66 & 6 & 48 & 85 & 8 \\
\hline Soya & 20 & 68 & 1 & 45 & 60 & 2 & 20 & 61 & 3 & 95 & 175 & 3 \\
\hline Average & 30 & 68 & 2 & 42 & 77 & 2 & 23 & 64 & 5 & 72 & 130 & 6 \\
\hline
\end{tabular}

Comparison of the data obtained on the control variant and sowing after only stubble siderat shows that in the field of sideral fallow the number of cereal weeds decreased by 38 $\%$, and the number of annual dicotyledonous weeds siderat had almost no effect. Reduction was only $3 \%$. However, the number of perennial dicotyledonous weeds tripled. In the soybean crop a similar pattern was observed, except that the number of cereal weeds did not change here, and the decrease in the number of annual dicotyledonous weeds was $7 \%$.

If during the cultivation of crops mineral fertilizers were used, crop residual siderat led to the growth of all types of weeds. Thus, in the field of green manure under the variant using only mineral fertilizers, without stubble siderat, there were on average $38 \mathrm{ex} / \mathrm{m}$ of ${ }^{2}$ cereal 
weeds, $94 \mathrm{ex} / \mathrm{m}$ of ${ }^{2}$ annual dicotyledons and $2 \mathrm{ex} / \mathrm{m}^{2}$ of perennial dicotyledonous weeds. At the same time, the number of cereal specimens was $21 \%$ higher and the number of perennial dicotyledonous weeds increased fourfold in the plots where residual siderat was sown and mineral fertilizers were applied. Soybean crops where mineral fertilizer and crop siderate were applied were more than 2 times more infested with cereal weeds, almost 3 times more with annual dicotyledons, and 1.5 times more with perennial dicotyledonous weeds, compared to plots with only mineral-fed crops. (Table 7)

In 2006-2009, the yield of pea grains sown after the crop siderat had no significant differences from the productivity of crops without it and was, respectively, $17.2 \mathrm{c} / \mathrm{ha}$ and 18.1 c/ha. That is, the crop siderat had an insignificant positive effect on the yield of peas, increasing the grain yield by $0.9 \mathrm{c} /$ ha relative to the control. At the same time, the yield of this grain legume when growing only with mineral nutrition was $19.6 \mathrm{c} / \mathrm{ha}$, and when using mineral fertilizer and crop siderat was slightly, by $0.3 \mathrm{c} /$ ha, higher. The yield of soybean for grain after a single crop siderat slightly decreased by $0.1 \mathrm{c} / \mathrm{ha}$, and when using mineral fertilizer and crop siderat did not significantly increase by $0.4 \mathrm{c} / \mathrm{ha}$. (Table 8 )

Table 8. Crop yields in the crop rotation with the use of stubble sowing of green manure depending on the applied fertilizer system in 2006-2009 and 2017-2020, c/ha.

\begin{tabular}{|c|c|c|c|c|c|c|c|c|c|c|}
\hline \multirow{3}{*}{ Crop rotation } & \multicolumn{8}{|c|}{ Fertilizer system } & \multirow{2}{*}{\multicolumn{2}{|c|}{$\begin{array}{c}\text { Least } \\
\text { significant } \\
\text { difference at } \\
5 \% \text { significance } \\
\text { level }\end{array}$}} \\
\hline & \multicolumn{2}{|c|}{$\begin{array}{l}\text { Without } \\
\text { fertilizer } \\
\text { (control) }\end{array}$} & \multicolumn{2}{|c|}{$\mathrm{N}_{30} \mathrm{P}{ }_{30} \mathrm{~K} 30$} & \multicolumn{2}{|c|}{ Stubble grass } & \multicolumn{2}{|c|}{$\begin{aligned} & \mathrm{N}_{30} \mathrm{P}_{30} \mathrm{~K}_{30} \\
+ & \text { Stubble grass }\end{aligned}$} & & \\
\hline & $\begin{array}{l}2006- \\
2009 .\end{array}$ & $\begin{array}{l}2017- \\
2020 .\end{array}$ & $\begin{array}{l}2006- \\
2009 .\end{array}$ & $\begin{array}{l}2017- \\
2020 .\end{array}$ & $\begin{array}{l}2006- \\
2009 .\end{array}$ & $\begin{array}{l}2017- \\
2020 .\end{array}$ & $\begin{array}{l}2006- \\
2009 .\end{array}$ & $\begin{array}{l}2017- \\
2020 .\end{array}$ & $\begin{array}{l}2006- \\
2009 .\end{array}$ & $\begin{array}{l}2017- \\
2020 .\end{array}$ \\
\hline $\begin{array}{l}\text { 1. Winter wheat } \\
\text { precursor* }\end{array}$ & 17,2 & 76,9 & 19,6 & 109,1 & 18,1 & 77,3 & 19,9 & 112,7 & 1,4 & 10,8 \\
\hline 2. Winter wheat & 40,6 & 52,9 & 46,7 & 69,0 & 42,1 & 55,9 & 46,8 & 70,0 & 3,6 & 2,1 \\
\hline 3. Soya & 20,5 & 21,6 & 21,5 & 22,0 & 20,4 & 20,9 & 20,9 & 20,6 & 1,3 & 1,2 \\
\hline 4. Spring wheat & 35,6 & 35,4 & 40,1 & 44,4 & 37,7 & 37,5 & 39,7 & 44,5 & 3,9 & 1,7 \\
\hline
\end{tabular}

In 2006-2009, peas for grain; in 2017-2020, green peas for grain; in 2017-2020, green peas for grain.

The same situation was with crop yields in 2017-2020. In this period, the winter wheat was preceded by green manure. It is worth noting that the value of green mass harvesting of green mass of the syderal steam, without separation into weeds and cultivated plants, after the crop siderat increased as a result of the growth of weed infestation.

Soybean crops after crop siderat were suppressed by weeds, especially perennial weeds, and its yield decreased more than in 2006-2009. Thus, without fertilizers soybean grain yield was $21.6 \mathrm{c} / \mathrm{ha}$, and after stubble siderat it gave $0.7 \mathrm{c} /$ ha less. When only mineral fertilizers were used, the yield of soybean grain was $22.0 \mathrm{c} / \mathrm{ha}$, and when they were used together with green manure, the yield of leguminous crops decreased significantly, by $1.4 \mathrm{c} / \mathrm{ha}$, to 20.6 $\mathrm{c} / \mathrm{ha}$. This was due to the high weediness of the preceding crop siderat.

Among the systems of fertilizers studied in the experiment, a significant increase in grain yield, both winter and spring wheat relative to the variant without fertilizers was obtained on the crops with mineral fertilizer $\mathrm{N}_{30} \mathrm{P}{ }_{30} \mathrm{~K}{ }_{30}$ and green manure used in conjunction with mineral fertilizer. Application of a single siderat in 2006-2009 did not contribute to the increase in yield relative to the control, and in 2017-2020, the yield increase only slightly exceeded the smallest significant difference. (Table 8)

Under grain crop rotation in 2006-2011 without the use of fertilizers humus balance was predominantly and generally negative (Table 9). Thus, by years the loss of humus ranged 
from $0.1 \mathrm{t} / \mathrm{ha}$ to $0.4 \mathrm{t} / \mathrm{ha}$, and on average the value of the balance in the control variant was negative and amounted to minus $0.2 \mathrm{t} / \mathrm{ha}$.

The application of mineral fertilizers, incorporation of crop siderat and combined use of these fertilizers contributed to an increase in humus inflow and a shift of its balance in the positive direction. At the same time the most positive balance of humus for this period was by mineral-sideral fertilizer system. According to literature sources, this degree of transformation of organic matter is estimated as the predominance of humification over its mineralization in the soil [11, p. 69].

Change of crop rotation to green manure in 2012 with replacement of grain legume precursors of winter wheat to green manure fallow significantly increased the flow of organic matter into the soil and the new formation of humus.

In 2012-2020 the average annual value of humification of organic matter in all variants of the experience increased (Table 9). The trends noted in the grain crop rotation by variants of the experience, remained in the sideral. Thus, the lowest average value of humus formation was in the control variant, where no fertilizers were used, although due to green manure it increased by almost $0.9 \mathrm{t} / \mathrm{ha}$ relative to the previous crop rotation.

Table 9. Humus balance in the $0-20 \mathrm{~cm}$ layer depending on the fertilizer system in $2006-2020, \mathrm{t} / \mathrm{ha}$.

\begin{tabular}{|c|c|c|c|c|}
\hline \multirow{2}{*}{ Years } & \multicolumn{4}{|c|}{ Fertilizer system } \\
\cline { 2 - 5 } & No fertilizer & Mineral & Sideral & Mineral-sederal \\
\hline 2006 & $-0,3$ & $-0,1$ & 0,1 & 0,2 \\
\hline 2007 & $-0,1$ & 0,1 & 0,2 & 0,4 \\
\hline 2008 & 0,1 & 0,2 & 0,2 & 0,3 \\
\hline 2009 & 0,0 & 0,2 & 0,4 & 0,6 \\
\hline 2010 & $-0,4$ & 0,0 & 0,0 & 0,2 \\
\hline 2011 & $-0,2$ & 0,0 & $-0,1$ & 0,1 \\
\hline $\begin{array}{c}\text { On average over } \\
2006-2011 .\end{array}$ & $-0,2$ & 0,1 & 0,1 & 0,3 \\
\hline 2012 & 1,0 & 1,1 & 1,1 & 1,3 \\
\hline 2013 & 0,7 & 1,0 & 1,9 & 2,0 \\
\hline 2014 & 1,3 & 1,4 & 1,0 & 1,2 \\
\hline 2015 & 0,7 & 0,6 & 0,9 & 1,1 \\
\hline 2016 & 1,0 & 1,7 & 0,9 & 1,6 \\
\hline 2017 & 0,4 & 0,9 & 0,5 & 0,9 \\
\hline 2018 & 0,4 & 0,8 & 0,5 & 0,9 \\
\hline 2019 & 0,3 & 0,5 & 0,3 & 0,5 \\
\hline 2020 & 0,7 & 1,0 & 0,7 & 0,9 \\
\hline $\begin{array}{c}\text { On average for } \\
2012-2020 .\end{array}$ & 0,7 & 1,0 & 0,9 & 1,2 \\
\hline $\begin{array}{c}\text { On average over } \\
\text { the period 2006- } \\
2020 .\end{array}$ & 0,4 & 0,6 & 0,6 & 0,8 \\
\hline $\begin{array}{c}\text { Total for 2006- } \\
2020 .\end{array}$ & 5,6 & 9,4 & 8,6 & 12,2 \\
\hline
\end{tabular}

Mineral fertilizer application provided a higher humus balance than the application of crop siderat, and it was equal to an average of $1.0 \mathrm{t} /$ ha per year. This level of positive humus balance was achieved by increasing the crop yield compared to the control, which was accompanied by a higher inflow of organic matter into the soil in the form of straw and croproot residues. 
Crop yield in the variant with green manure was almost in all years at the same level as the control without a statistically significant increase or decrease. Therefore, the increase in the arrival of organic matter here was due to the use of crop siderat.

Sowing of stubble siderat against the background of mineral fertilization under all crops of the crop rotation increased the yield of its green mass, which on average for 9 years yielded the highest in the experiment the amount of organic matter and, therefore, humus formation, which gave the highest in the experiment positive balance of humus at $1.2 \mathrm{t} / \mathrm{ha}$ per year.

Thus, the data obtained indicate that the orientation and degree of transformation of organic matter in the soil by the studied systems of fertilizers is different. Under the variants with siderat, with mineral fertilizer and without fertilization occurs, according to the established estimates, humification, and with the joint use of mineral and stubble siderat fertilizer is active humification [11, p. 69].

\section{Conclusions}

Winter wheat in the experiment was harvested earlier than spring wheat, and due to this sown on its stubble more often found itself in more favorable conditions to give seedlings and higher yields. Sowing it after spring wheat at a later date did not give the practical expected result.

Perennial application of crop siderat generally led to an increase in the weed infestation of the field by perennial dicotyledonous weeds by 3-4 times regardless of the use of mineral fertilizers. However, the weed infestation of the crop by annual weeds following the crop siderat slightly increased in the variants with mineral fertilizers, and decreased when they were abandoned. Stubble siderat had no significant effect on the yield of the next crop.

Cultivation of stubble siderat, due to transformation of additional organic matter, created conditions for predominance of humification process over mineralization, which provided a positive balance of humus in the soil.

\section{References}

1. E.V. Truflyak et al. Monitoring and forecasting of scientific and technological development of agroindustrial complex of Russia for the period up to 2030, 328 (Publishing house: LLC "Amirit" (Saratov), 2020)

2. I. G. Pykhtin, D. V. Dubovik, Current problems in farming, 5, 8-11 (2018) DOI:10.24411/0044-3913-2018-10502.

3. S. V. Lukin, Achievements of science and technology of the agroindustrial complex, 30 (7), 20-23 (2016)

4. B. M. Kogut, Agrogenic transformation of the humus state of Russian chernozem, Model technology of agriculture optimization: collection of reports of the International Scientific and Practical Conference 145-148 (Kursk, VNIIZPE, 2003)

5. S. V. Lukin, E. A. Zazdravnykh, E. A. Prazina, Achievements of Science and Technology of the Agricultural Complex 33 (3), 15-18 (2019)

6. M. A. Nesmeyanova, A. V. Dedov, Bulletin of the Omsk State Agrarian University 1 (29), 35-42 (2018)

7. A. V. Dedov, M. A. Nesmeyanova, Agrochemical Bulletin 4, 7-9 (2012)

8. S.I. Smurov, G.S. Agafonov, O.V. Gapienko, Achievements of science and technology of agroindustrial complex 9, 11-14 (2008) 
9. A. V. Dedov, M. A. Nesmeyanova, Binary crops - one of the directions of organic agriculture development in the Central Chernobyl Region, Proceedings of the conference "Actual problems of agronomy in modern Russia and ways of their solutions", 37-41 (2018)

10. Y. G. Mischenko, I. N., Masik, Science and World, 2, 5 (33), 76-79 (2016)

11. G. I. Uvarov, V. D. Solovichenko, Degradation and protection of soils of Belgorod Oblast: monograph, 180 (Belgorod: "Otchiy Kray", 2010)

12. N.P. Masyutenko, Transformation of organic matter in the chernozem soils of the Central Black Earth Region and the system of its reproduction, 150 (Moscow: Russian Agricultural Academy, 2012)

13. Miguel Angel Florentín, Marcos Peñalva, Ademir Calegari, Rolf Derpsch. Green manure/cover crops and crop rotatiion iin Conservatio Agriicullture on small farms, Integrated Crop Management Vol.12-2010. Plant Production and Protection division Food and agriculture organization of the united nations Rome, 109 (2011) ISBN 97892-5-106856-4

14. C.A. Campbell, V.O. Biederbeck, R.P. Zentner, G.P. Lafond, Journal Soil Science 71, 363-376 (1991)

15. W.O. Enwezor, Plant and Soil 44, 237-240 (1976)

16. G. Goodlass, D.J. Hatch, M.A. Shepherd, J.A. King, S.P. Cuttle, S. Roderick, S. Briggs, Aspects of Applied Biology 79, 269-270 (2006)

17. A. N'Dayegamiye, T.S. Tran, Journal of Soil Science 81, 371-382 (2001)

18. M. Liebman, A.S. Davis, Weed Research 40, 27-47 (2000)

19. H. Pung, P. L. Aird, S. Cross, The use of brassica green manure crops for soil improvement and soilborne disease management 3rd Australasian Soilborne Diseases Symposium 8-11 February 2004 (2005) 